\title{
Preparation of $\mathrm{MgO}-\mathrm{MnO}_{2}$ nanocomposite particles for cholesterol sensors
}

\author{
Alaa A. Abdul-Hamead ${ }^{1, *}$, Farhad M. Othman ${ }^{1}$, and Makram A. Fakhri ${ }^{2, *}$ (1) \\ ${ }^{1}$ Department of Materials Engineering, University of Technology/Baghdad-IRAQ, Baghdad, Iraq \\ ${ }^{2}$ Laser and Optoelectronic Engineering Department, University of Technology, Baghdad, Iraq
}

Received: 10 December 2020

Accepted: 2 May 2021

Published online:

22 May 2021

(C) The Author(s), under exclusive licence to Springer Science+Business Media, LLC, part of Springer Nature 2021

\begin{abstract}
Various nanoparticles have been developed for bio-applications. However, nanocomposites particles, (NCPs) with effective and ability to sensing cholesterol, are still needed. Herein, we present new cholesterol and $\mathrm{pH}$-responsive NCPs as sensor particles to promote sensitivity. The traditional method of mixing and grinding was used to fabricate the oxides of magnesium and manganese $\mathrm{MgO}-\mathrm{MnO}_{2} \mathrm{NCPs}$ with different mixing ratios. Structural properties, detection of cholesterol, and $\mathrm{pH}$ sensitivity were examined. Results propped the high efficiency of $\mathrm{MgO}-\mathrm{MnO}_{2} \mathrm{NCPs}$ compared with individual oxides $\left(\mathrm{MgO}\right.$ and $\left.\mathrm{MnO}_{2}\right)$, low response time, while the analytical results confirmed the homogeneous structure of $\mathrm{MgO}-\mathrm{MnO}_{2} \mathrm{NCPs}$. Particle size distribution results for NCPs were within 16.4 to $100 \mathrm{~nm}$, which makes it promising in medical and bio-applications.
\end{abstract}

\section{Introduction}

Intelligent use of physiological activity monitoring gadgets such as heart rate monitors, step or calorie counting devices, or even lactate threshold monitoring patches became senior. The aim is to get information without exceeding especially patient privacy and for monitored healthcare and patients [1]. With the emergence of the coronavirus disease-2019 (COVID-19), the importance of monitoring the cardiovascular and vital functions has increased for workers and patients [2].

All of this increased the demand for bio- and biomedical sensors which are exceptional electronic devices that can transduce biomedical signals into easily measurable electric signals [3]: physical, chemical, and biological quantity sensors. Biological quantity sensors are sensors used to detect biological parameters such as tissues, cells, enzymes, antigens, antibodies, receptors, hormones, cholic acid, acetylcholine, cholesterol, serotonin, DNA, and RNA, and other proteins. Cholesterol is an organic molecule that is created by the human body to maintain cell membrane temperature. High levels of cholesterol can narrow the arteries and raised the risk of heart disease. Cholesterol has several types such as low-density lipoprotein (LDL) or bad cholesterol, high-density lipoprotein (HDL), or good cholesterol-the bad cholesterol eater and Lp (a) cholesterol. Metal oxides $\mathrm{MOx}$ such as $\mathrm{SnO}_{2}, \mathrm{ZnO}$, $\mathrm{CuO}, \mathrm{CeO}, \mathrm{NiO}$, and $\mathrm{MnO}_{2}$ have different sensing

Address correspondence to E-mail: 130043@uotechnology.edu.iq; mokaram_76@yahoo.com; 140017@uotechnology.edu.iq 
ranges to Cholesterol [4, 5]. Another biomarker sign is monitoring the stability of $\mathrm{pH}$ of organs such as the heart diverse $\mathrm{MOx}$ for $\mathrm{pH}$ sensors, $\mathrm{IrO}_{2}, \mathrm{WO}_{3}, \mathrm{RuO}_{2}$, $\mathrm{TiO}_{2}, \mathrm{Ta}_{2} \mathrm{O}_{5}$, and $\mathrm{ZnO}$ which were employed. [6-8] Magnesium oxide $\mathrm{MgO}$ is a wide inorganic substance including a broad band-gap. It has been used in various fields such as in bio-medicine $[9,10]$. $\mathrm{MgO}$ has been applied for bone repair, the release of heartburn, and in the sensitive stomach, pharmaceutical applications. Recently, $\mathrm{MgO}$ nanoparticles have been used in cancer therapy besides having considerable activities as an antibacterial agent [11]. MgO nanoparticles [12, 13] Several researchers present various approaches for $\mathrm{MgO}$ nanostructure synthesis like nano-bundles (thermal evaporation method) [14], nanorods (magnesium chloride solution was bio-reduced to magnesium oxide nanorods using Tectona grandis leaves extract) [15, 16]; nanosheets cryptocrystalline magnesite was converted into $\mathrm{MgO}$ nanosheets using thermal activation and ball milling [17]. Nano-flower displayed a biological method for synthesis of magnesium oxide $(\mathrm{MgO})$ nanoflowers by using Aqueous Rosemary [18]. Nanobelt was obtained by magnesium nitrate decomposition using the direct arc plasma jet chemical vapor deposition technique, with a molybdenum substrate [19]. Nanotetrapods (Tubular tetrapod magnesium oxide (tt-MgO) can be synthesized by thermal evaporation of $\mathrm{Mg}$ metal powder with a pre-grown tetrapod $\mathrm{ZnO}$ template.) [20] Hierarchical nanostructure (also 3D hierarchical flowerlike $\mathrm{MgO}$ microstructure ( $\mathrm{HFl}-\mathrm{MgO}$ ), which was synthesized by chemical precipitation method [21, 22]. Hollow mesoporous $\mathrm{MgO}$ nanospheres (HMMN) have been demonstrated by the coating of carbon spheres template with $\mathrm{MgO}$ nanoparticles, then the calcination in the presence of air to remove the carbon core at elevated temperature [23].

On the one hand, the synthesis of the $\mathrm{MgO}$ nanocomposite gets received widespread attention, like $\mathrm{CuO}-\mathrm{MgO}$ nanocomposites (prepared by a solvothermal procedure for catalytic applications) [24, 25], $\mathrm{Y}_{2} \mathrm{O}_{3}-\mathrm{MgO}$ nanocomposite (by ceramics powder sintering) [26], $\mathrm{CdO}-\mathrm{MgO}$ (microwave-assisted method) [27-29], $\mathrm{MgO}-\mathrm{Fe}_{2} \mathrm{O}_{3}$ nanocomposite (was prepared via a simple precipitation route) [30, 31], $\mathrm{ZnO}-\mathrm{MgO}$ (formed by the sol-gel method) $[29,30], \mathrm{Ag}_{2} \mathrm{~S}-\mathrm{MgO} /$ graphene (was prepared via solgel/ultrasound method) [32, 33] $\mathrm{Al}_{2} \mathrm{O}_{3}-\mathrm{MgO}$ (synthesized by a sol-gel process) [34], $\mathrm{CaCO}_{3}-\mathrm{MgO}$ (synthesized $\mathrm{MgO}$ nanoparticle-coated eggshell particles (defined as $\mathrm{CaCO}_{3} / \mathrm{MgO}$ nanocomposites) and subsequently manufactured a biomimetic active scaffold via the chemical crosslinking) [35]. $\mathrm{Y}_{2} \mathrm{O}_{3}-$ $\mathrm{MgO}$ (colloidal technique and SPS spark-plasmasintering (SPS) techniques.) [36].

Yet the mill method is still an exciting technique to prepared nanomaterials [37, 38] and nanocomposite such as WC-MgO [39]. The ball milling method with High-energy was a functional procedure fit for achieving solid-state of various alloy systems, nanocrystalline and nanocomposite materials. The main characterized of the milling method was industrial significance, room temperature process and high-thermal stability. The important parameters were milling time to milling speed (TV) and ball-to-powder weight ratio (BPR) [40]. Manganese oxide $\mathrm{MnO}_{2}$ is also interesting due to its properties and dependable in sensors by their different nanostructure like tunnel structures [41], nanosheet [42], nanowires [43], nanorods [44], nano-flower [45], nanosphere [46]. Different methods were used to analyze cholesterol percentages; electrochemical method is a simple and promising method procedure for biosensor applications. The $\mathrm{pH}$ sensors depend on diverse mechanisms (e.g. potentiometric, conductometric, chemi-resistors, and ion-sensitive field-effect transistor (ISFET), etc.) $[47,48]$.

Our work issues a wide insight into the $\mathrm{MgO}$ $\mathrm{MnO}_{2}$ nanocomposite particles utilizing different weight mixture percentages to construct highly sensitive and rapidly responsive cholesterol sensors.

\section{Experimental methods}

\subsection{Preparing $\mathrm{MgO}-\mathrm{MnO}_{2}$ nanocomposite}

The experimental steps to prepare $\mathrm{MgO} / \mathrm{MnO}_{2}$ nanocomposite particles NCPs are listed below.

The oxides $\mathrm{MgO}: \mathrm{MnO}_{2}$ (high purity $99 \%$ provided from HUBEI AOKS BIO-TECHCO., LTD.) with $(10 \mu \mathrm{m})$ average size. The mix weight ratios were five (100:0, 75:25, 50:50, 25:75, 0:100 wt \%) denominate by NCPs ${ }_{1-5}$, respectively. After determining the exact weights and ratios of the raw materials, we added them to ethanol Alcohol suspension and homogenized using the ultrasonic device about $30 \mathrm{~min}$ type (Hielscher) with the power of $2 \mathrm{~W}$ and frequency $26 \mathrm{kHz}$ and $1000 \mathrm{rpm}$ to ensure uniformity of distribution. Then, the mixes were milled by using a friction mill for $4 \mathrm{~h}$.

After that drying process within an oven of type IMS was used at a temperature of $60 \pm 5^{\circ} \mathrm{C}$, for $3 \mathrm{~h}$. 
The gotten mixed powders were sintered at $400{ }^{\circ} \mathrm{C}$ for $1 \mathrm{~h}$ by MTI CORPORATION, GSL1600X furnace.

\subsection{Inspection of $\mathrm{MgO} / \mathrm{MnO}_{2}$ nanocomposite}

\subsubsection{Structural properties}

Energy-dispersive x-ray (EDX) spectra were recorded using a scanning electron microscope (SEM) study, carried out by electron gun tungsten, secondary electrons detector mode, ultrahigh vacuum $\left(10^{-6} \mathrm{bar}\right)$, $20 \mathrm{kV}$ of accelerating voltage, and variable working distance; SEM MAG was 10.0KX (Type TESCAN VEGA III) (CZECH). The nature and the crystal growth of the $\mathrm{MgO} / \mathrm{MnO}_{2}$ nanocomposites were examined by X-ray diffraction XRD. The measurements were made by using Philips PW 1050 X-ray diffractometer of (1.5406) $\AA$; copper K $\alpha$ radiation was used. The particle size test for particles was performed by (Brookhaven Nano-Brook 90 plus USA).

\subsubsection{Samples preparation}

The method was used to determine the cholesterol in blood samples. The samples were prepared by using $5 \mathrm{ml}$ of blood sample centrifuged (by Centrifuge type 903485 Taiwan) to get $1 \mathrm{ml}$ of serum. The separated part was extracted and mixed using $10 \mathrm{~mL}$ of total dissolved solids water TDS water and sonicated for $15 \mathrm{~min}$ with (Biobase Biodustry (Shandong) Co., Ltd., China).

\subsubsection{Cholesterol measurement}

The dispersed NCPs have higher sensitivity, functionalized electrodes and conductivity. Figure 1 shows the experimental steps for measurement. Sensor preparation for cholesterol measurements was performed by adding $500 \mu \mathrm{L}$ (Syringe $1750 \mathrm{~N}$ CTC, $(26 / 51 / A S))$ at $5 \mathrm{wt} \%$ NCPs into an Eppendorf tube (Conical Tubes). A $40 \mu \mathrm{L}$ of the solution was drop cast onto SPCE for cyclic amperometry measurements using Drop Send DRP-STAT400 (Electrochemical measurements using two electrodes to measure current nA range). Then, a volume of $40 \mu \mathrm{L}$ of cholesterol solutions, with various concentrations $(25,50,75,100,125$, and 150) $\mu \mathrm{l}$, was added into another Eppendorf tube, mixed, and kept for $20 \mathrm{~min}$. After that, it is compared with the readings of the tests of real patients of different ages and different blood groups to verify the values obtained. The readings were using the Randox Rx Daytona.

\subsection{4 pH measurements}

Effect of Ionic Strength. To check the effect of ionic strength on the $\mathrm{pH}$ sensing ability of NCPs, $50 \mu \mathrm{L}$ fraction of NCPs $\mathrm{N}_{1-5}$ solution and a volume of $50 \mu \mathrm{L}$ of cholesterol solutions of different concentrations were taken. The $\mathrm{pH}$ measurements were done by using $\mathrm{pH}$ meter type CRISON.

\section{Results and discussion}

\subsection{X-ray diffraction results}

Figure 2 shows the XRD patterns of specimens with angular scanning range of $\left(30-80^{\circ}\right)$, for the $\mathrm{MgO}$ pure and modified with $\mathrm{MnO}_{2}$ nanocomposites at a: $(0,25,50,75,100$ wt \%) in (a, b, c, d, and e) represented by $\mathrm{NCPs}_{1-5}$.
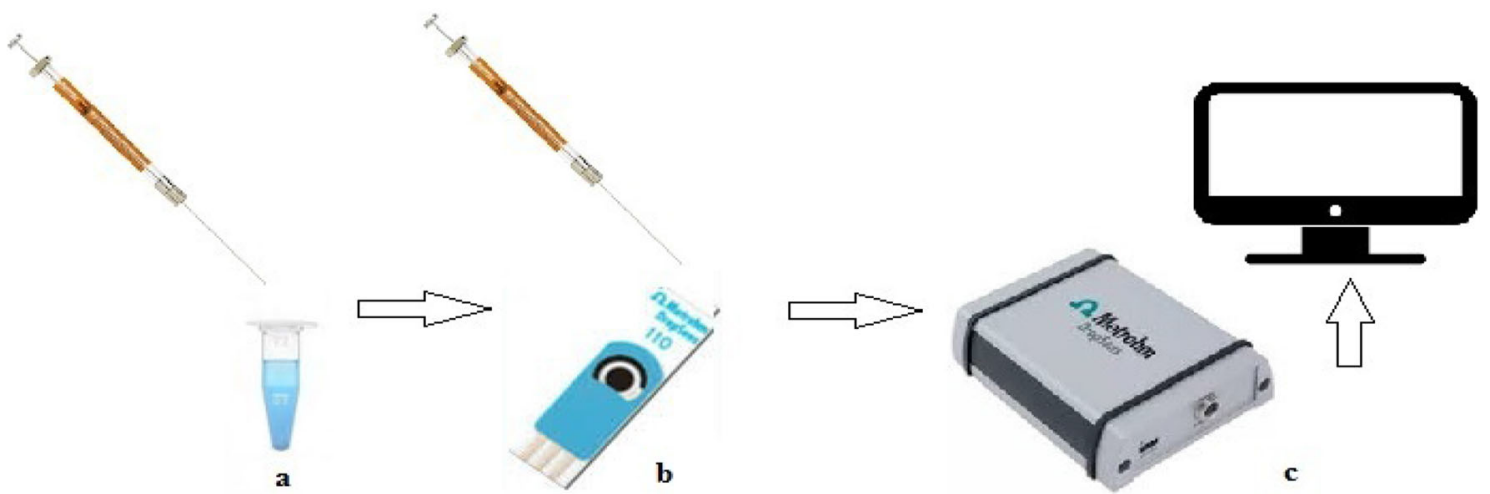

Fig. 1 Schematic experimental steps for measurement, a mixing, b dropping and cmeasuring 
The NCPs1 Fig. 2a is $\mathrm{MgO}$ polycrystalline nanoparticles consisted of pure single-phase cubic system agreed with the JCPDS database card No. (30-0794). The XRD pattern of the $\mathrm{MgO}$ shows five peaks at $38.44^{\circ}, 44.37^{\circ}, 59.18^{\circ}, 64.52^{\circ}$, and $73.33^{\circ}$ attributed to the (222), (400), (511), (440) and the (620) planes; the (400) is the preferred orientation formed. No crystalline impurity phases were observed $[49,50]$.

On the one hand, the NCPs5 Fig. 2e is $\beta-\mathrm{MnO}_{2}$ polycrystalline nanoparticles consisted of pure single tetragonal phase system agreed with the JCPDS database card No. (24-0735).

The XRD pattern of the $\mathrm{MnO}_{2}$ also shows six peaks at $37.33^{\circ}, 42.83^{\circ}, 56.65^{\circ}, 59.37^{\circ}, 72.26^{\circ}$, and 72.38 attributed to the (101), (111), (211), (220), (301), and the (112) planes; the (101) and (211) are the preferred orientation planes formed [51].

The samples $\mathrm{NCPs}_{2}, \mathrm{NCPs}_{3}$, and $\mathrm{NCPs}_{2}, 3,4$ in Fig. $1 \mathrm{~b}-\mathrm{d}$, respectively, for $\mathrm{MgO}-\mathrm{MnO}_{2}$ nanocomposites, both pure phases $\mathrm{MgO}$ and $\beta-\mathrm{MnO}_{2}$ were presented in different planes intensities, consistent with the proportions of mixing and preparation. And to verify the homogeneity of the formed nanocomposites particles additional realization was carryout via calculation of the lattice constants, lattice strain, and texture coefficient.

Lattice strain $\delta$ percentage broadening is caused by changes in displacements of the atoms concerning their reference lattice position, evaluated from equation [52-54]:

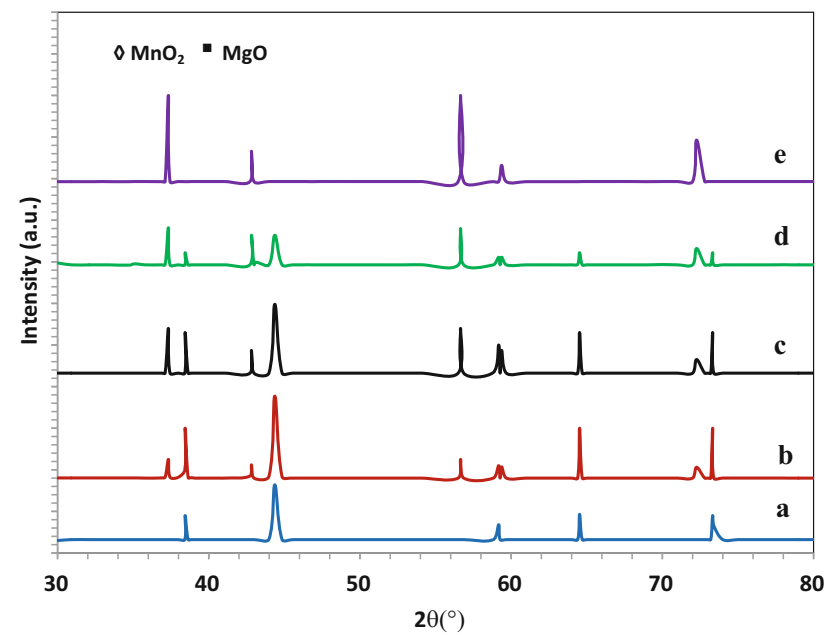

Fig. 2 XRD patterns of a $\mathrm{NCPs}_{1}$ and $\mathbf{b} \mathrm{NCPs}_{2}, \mathbf{c} \mathrm{NCPs}_{3}$, $\mathrm{dNCPs}_{4}$, e $\mathrm{NCPs}_{5}$
$\delta=\frac{D_{s}-D_{m}}{D_{s}} \times 100 \%$

where $D_{s}$ and $D_{m}$ are the standards and the measured lattice constants. For a certain crystal plane (hkl) in a polycrystalline particle, the orientation preferred was represented by [55]:

$T_{C}=\left(\frac{I_{m} / I_{\circ}}{M^{-1} \sum \frac{I_{m}}{I_{\circ}}}\right)$

where $T_{C}$ is the texture coefficient for a certain (hkl) plane, $I_{m}$ is the measured intensity value, $I_{o}$ is the JCPDS standard intensity value of the corresponding powder and $\mathrm{M}$ is the number of reflections observed in the XRD trace. The structural result from XRD data of $\mathrm{MgO}, \mathrm{MnO}_{2}$ NPs, and NCPs is in Table 1. The lattice constants were very close to card standard values, while the lattice strain and the texture coefficient can be acquired under the present synthetic conditions varying between pure NPs and NCPs, by the difference in lattice constants and the mixing ratio of the composites particles.

\subsection{SEM results}

Figure 3 illustrates the SEM images and particle size distribution of a: $\mathrm{MgO} N P s$ and $b: \mathrm{NCPs}_{2}, \mathrm{c}: \mathrm{NCPs}_{3}$, d: $\mathrm{NCPs}_{4}$, e: $\mathrm{MnO}_{2} \mathrm{NPs}_{5}$. In Fig. 3a the $\mathrm{MgO} \mathrm{NPs}$ have a homogeneous distribution of a rod-like composition and Avg. Diameter about $156.91 \mathrm{~nm}$ and cumulative lengths up to $10 \mu \mathrm{m}$, agree with [50], while Fig. 3e shows the SEM images and particle size distribution of $\mathrm{MnO}_{2} \mathrm{NPs}_{5}$. It shows a very fine spherical structure with Avg. Diameter: $102.71 \mathrm{~nm}$; the aggregation takes place to beat the higher surface energy because of the higher surface to volume ratio [56]. On the other hand, in Fig. $3 b$ for mixing ratio

Table 1 Structural result from $\mathrm{XRD}$ data of mix $\mathrm{MgO}, \mathrm{MnO} 2$ NPs, and NCPs

\begin{tabular}{llllll}
\hline & & $\mathrm{a} \AA$ & $\mathrm{c} \AA$ & $\delta\left(* 10^{-3}\right)$ & $\mathrm{T}_{\mathrm{c}}$ \\
\hline $\mathrm{NPs}$ & $\mathrm{NCPs}_{1}$ & 8.118 & - & 0.05 & 0.9 \\
$\mathrm{NCPs}$ & $\mathrm{NCPs}_{2}$ & 8.117 & - & 0.3 & 0.88 \\
& & 4.399 & 2.872 & & \\
& $\mathrm{NCPs}_{3}$ & 8.117 & - & 0.7 & 0.65 \\
& & 4.399 & 2.873 & & \\
& $\mathrm{NCPs}_{4}$ & 8.117 & - & 0.2 & 0.8 \\
& & 4.399 & 2.873 & & \\
$\mathrm{NPs}$ & $\mathrm{NCPs}_{5}$ & 4.398 & 2.874 & 0.02 & 0.92 \\
\hline
\end{tabular}



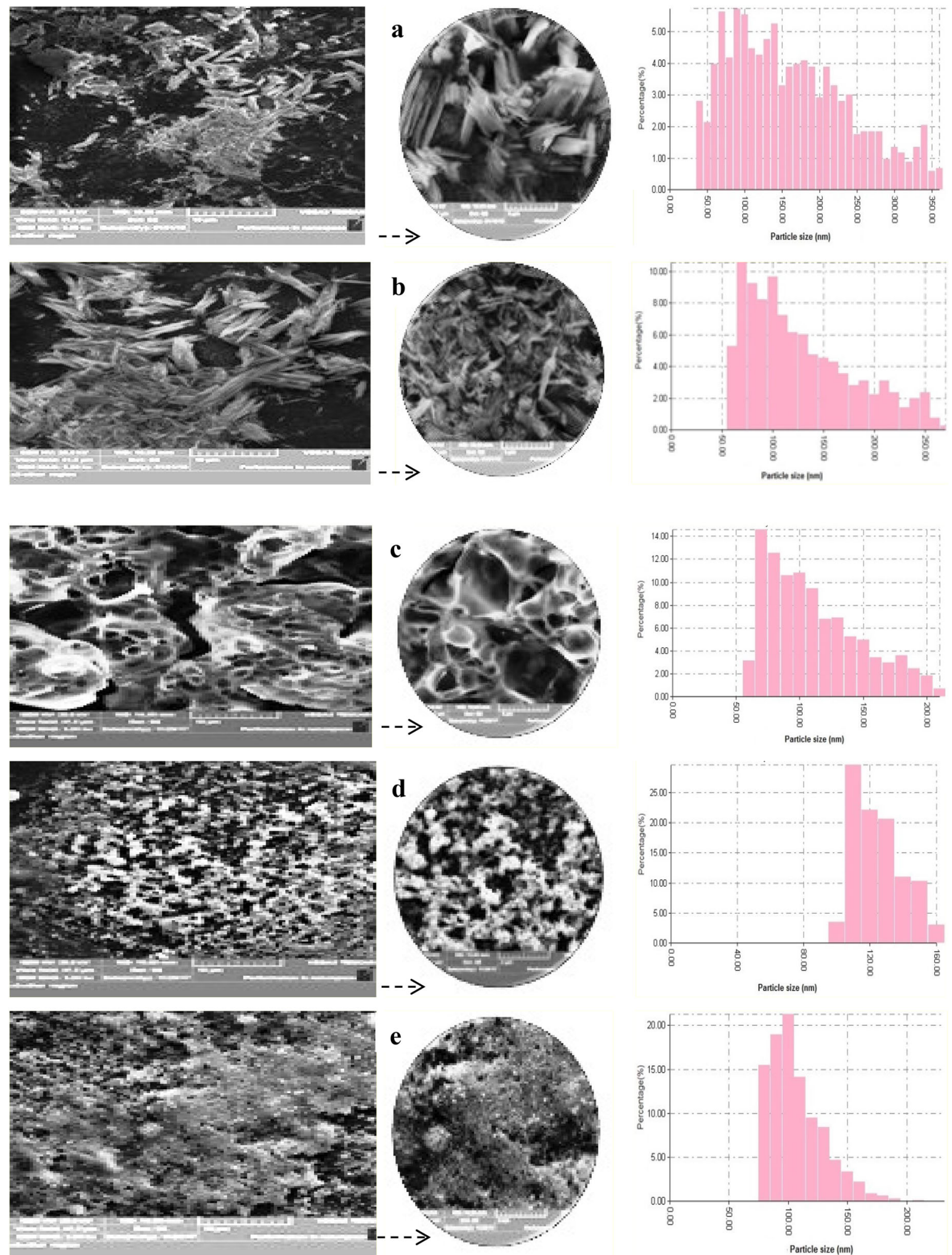

Fig. 3 SEM images and particle size of a NPs and $\mathbf{b} \mathrm{NCPs}_{2}, \mathbf{c ~ N C P s} s_{3}, \mathbf{d ~ N C P s} 4$, e $\mathrm{NPs}_{5}$ 
75\%:25\%, the rod-like composition, and Avg. Diameter present in Fig. 3. For $\mathrm{MgO} \mathrm{NPs}$ reduced with present $\mathrm{MnO}_{2}$ and formation $\mathrm{MgO}-\mathrm{MnO}_{2}$ nanocomposite with higher density and smaller Avg. The diameter reaches $123.53 \mathrm{~nm}$. And with an increase in the percentage of manganese oxide to 50\% the Avg. Diameter continues to drop to $106.71 \mathrm{~nm}$. And the composition turns into a semi-hollow (or tunnel) structure form composed of equal proportions of the oxides. This unique hollow shape transforms with an increasing proportion of $\mathrm{MnO}_{2}$ to a smooth semispherical shape compared to the previous composition of the ratios, Avg. Diameter return rising to $119.95 \mathrm{~nm}$. This diversity in morphology is due to the mechanism of energy transfer during the processes of grinding and mixing. In Fig. $3 \mathrm{~d}$ the $\mathrm{NCPs}_{4}$ has a semi-spherical structure.

\subsection{EDX results}

To identify the element distribution, EDX analysis of the specimens was performed. The EDX analysis shown in Fig. 4 the Micrograph image for $\mathrm{MgO}$, $\mathrm{MnO}_{2}$ nanoparticles (in a and e), and $\mathrm{MgO}-\mathrm{MnO}_{2}$ nanocomposites (in b, c, and d). Figure 4 shows the presence of $\mathrm{Mg}$ and $\mathrm{O}$ associated with the main percentage of the constituent elements (parent composition). The same goes for Fig. $4 \mathrm{e}, \mathrm{Mn}$, and $\mathrm{O}$ elements. Elemental analysis of $\mathrm{MgO}: \mathrm{MnO}_{2}$ mixed composite particles was confirmed by EDX characterization. The mixes M2, M3, and M4 contained Mg, $\mathrm{Mn}$, and $\mathrm{O}$ elements $[57,58]$.

\subsection{Particle size results}

Figure 5 demonstrates the particle-size distribution on the $\mathrm{MgO}$ and $\mathrm{MnO}_{2} \mathrm{NPs}$ (a: NCPs, e: NCPs5) with NCPs at different ratios (b: NCPs2, c: NCPs3, d: NCPs4).

In Fig. 5a the PZ of $\mathrm{MgO}$ was $1138 \mathrm{~nm}$ and $65 \%$ of the formed particles were below $1138 \mathrm{~nm}$. In Fig. 5e the $\mathrm{PZ}$ of $\mathrm{MnO}_{2}$ was $364 \mathrm{~nm}$ and $65 \%$ of the formed particles were below this value.

Composite nanoparticles were in b: $100 \mathrm{~nm}$, in c: $83 \mathrm{~nm}$, and in $\mathrm{d}: 16.4 \mathrm{~nm}$. It should be noted that this study showed that $50-65 \%$ of the formed particles were in the nano-range which can have a significant effect on the performance of the sensors.

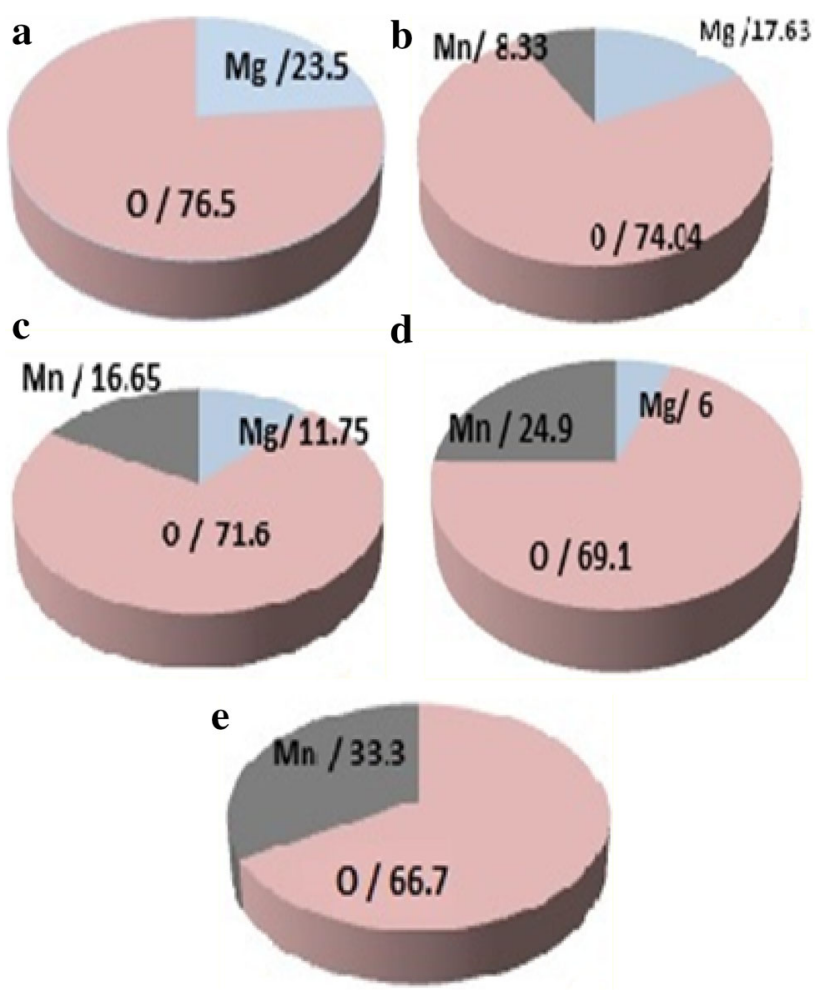

Fig. 4 EDX analysis ratio of $\mathbf{a} \mathrm{NPs}$ and $\mathbf{b} \mathrm{NCPs}_{2}, \mathbf{c} \mathrm{NCPs}_{3}$, $\mathrm{dNCPs}_{4}$, e $\mathrm{NPs}_{5}$

\subsection{Cholesterol sensor results}

Cholesterol sensor results are presented in Fig. 6; the current peak obtained from different Cholesterol concentrations is plotted as a function of sensing time. It shows a high rate increase during the first $20 \mathrm{~s}$, followed by a slight increase up to $80 \mathrm{~s}$ of examination time, and the result tends to be stable in the last $10 \mathrm{~s}$ of the examination time. This behavior is observed in all the prepared mixtures of nanocomposite oxides. The minimum detection time was $10 \mathrm{~s}$ in Fig. 6b: $\mathrm{NCPs}_{2}$ and in the c: $\mathrm{NCPs}_{3}$. And that is due to the hollow structure that increases the surface area of the reaction for this sensor. Through this analysis and by comparison with the measured values for actual patients, a match was found, suggesting the benefit of rapid detection compared to conventional methods.

\section{6 pH-sensing}

Figure 7 shows the results of $\mathrm{pH}$ for the prepared nanocomposites particles. In this test the molecular formula is $\mathrm{C}_{27} \mathrm{H}_{46} \mathrm{O}$ and heavy molecular weight 
(386.7 $\mathrm{g} / \mathrm{mol})$, topological polar surface Area is 20.1 $\AA^{2}$ with a density of about $1.067 \mathrm{~g} / \mathrm{cm}^{3}$, a white, crystalline substance that is odorless and tasteless prepared cholesterol was synthesized in vitro. Moreover, several healthy men and patients, male and female, were examined and compared with the laboratory value.

The results showed that all the prepared nanocomposites particles were highly sensitive to the change in the $\mathrm{pH}$ values under examination conditions. The results of healthy people subjects ranged from 7.35 to 7.45 for males and females, and for all nanoparticles superposed. The preeminent nanocomposites particles mixed were $\mathrm{NCPs}_{3}$ which matched with the reference sample. This is due to the hollow structure and the higher specific surface area presented in SEM in Fig. 3c. In un-healthy people's subjects, the detection of $\mathrm{pH}$ was more effective. As it recorded different heights and was in $\mathrm{NCPs}_{2}$ and $\mathrm{NCPs}_{3}$ better compared with single oxides $\left(\mathrm{NCPs}_{1}\right.$ and $\mathrm{NCPs}_{5}$ ), as the measurement sensitivity reached $2 \%$ for both men and women $[59,60]$.

Moreover, RX Daytona plus by Randox Laboratories Ltd, UK device was used to determine the real values of patients. As shown in Table 1the gender, average age, nanocomposites particles sensitivity $\mathrm{S} \%$, test results $t_{R}$, and a number of patients No. were illustrated.

Table 2 shows that all manufactured sensors have different detection ratios and match the actual results. And the best rate (in case of the absence of high cholesterol) was $77.3 \%$ for 23 males and 17 females with average ages 45,48 years, respectively, for $\mathrm{NCPs}_{3}$. In patients with high cholesterol, they are classified into two types: the first type Positive but Low, the sensors showed a remarkable match with the actual values. The best of them were $85 \%$ of males, number 11 with an average age and 53 years, and $84.1 \%$ for a female with number 34 an average age was 48 years. The second type is Positive High,
Fig. 5 Particle size distribution patterns of a NCPs and $\mathbf{b} \mathrm{NCPs}_{2}, \mathbf{c} \mathrm{NCPs}_{3}$, d $\mathrm{NCPs}_{4}$, e $\mathrm{NCPs}_{5}$
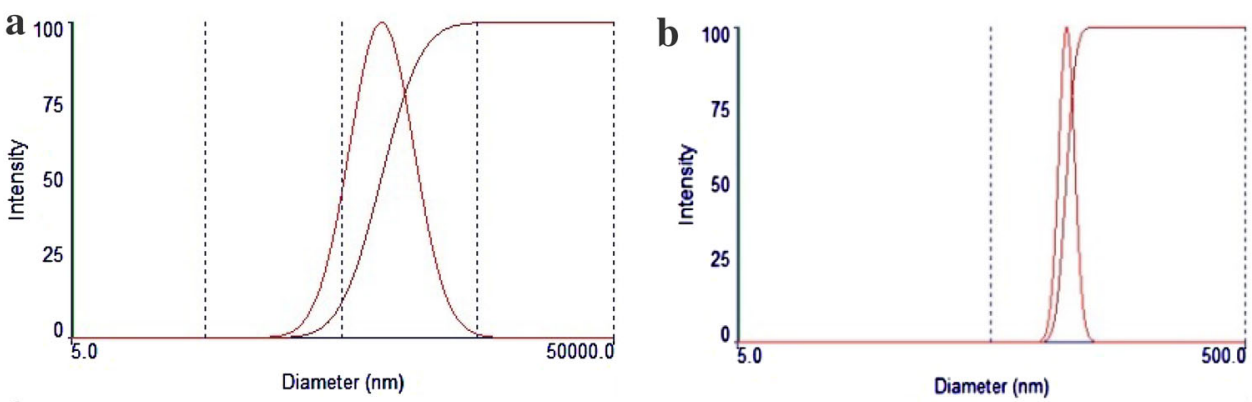

c

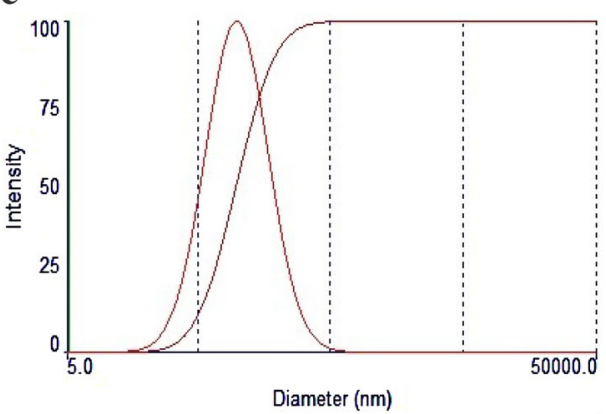

d

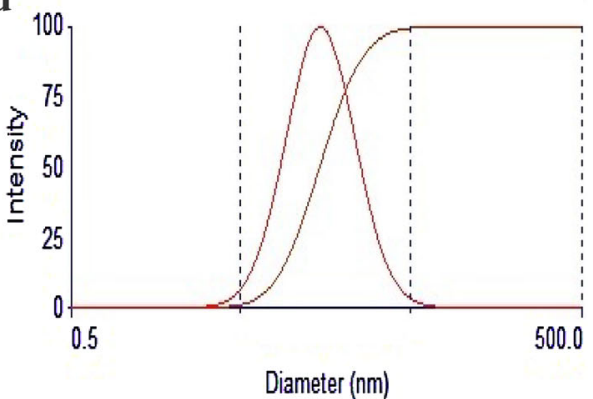

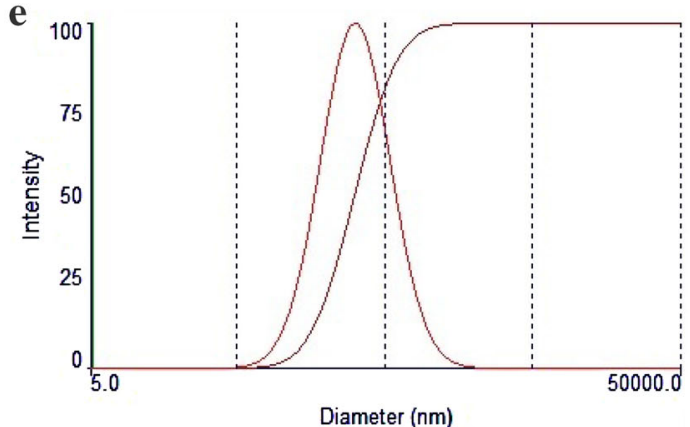


Fig. 6 Current results of a $\mathrm{MgO}$ NPs and $\mathbf{b} \mathrm{NCPs}_{2}$, c $\mathrm{NCPs}_{3}, \mathbf{d ~ N C P s} 4, \mathbf{e ~} \mathrm{MnO}_{2}$ $\mathrm{NPs}_{5}$

the correspondence rate with the actual results increased to $93 \%$. With the actual results, in the case of males, number 45 , with an average age of 63 years, and in the case of females, 92\%, number 14, with an average age of 55 years.

Moreover, the rest of the detectors also achieved a match with the actual values and there remains more than one option available, but $\mathrm{NCPs}_{3}$ an ideal choice for $\mathrm{pH}$ sensing.
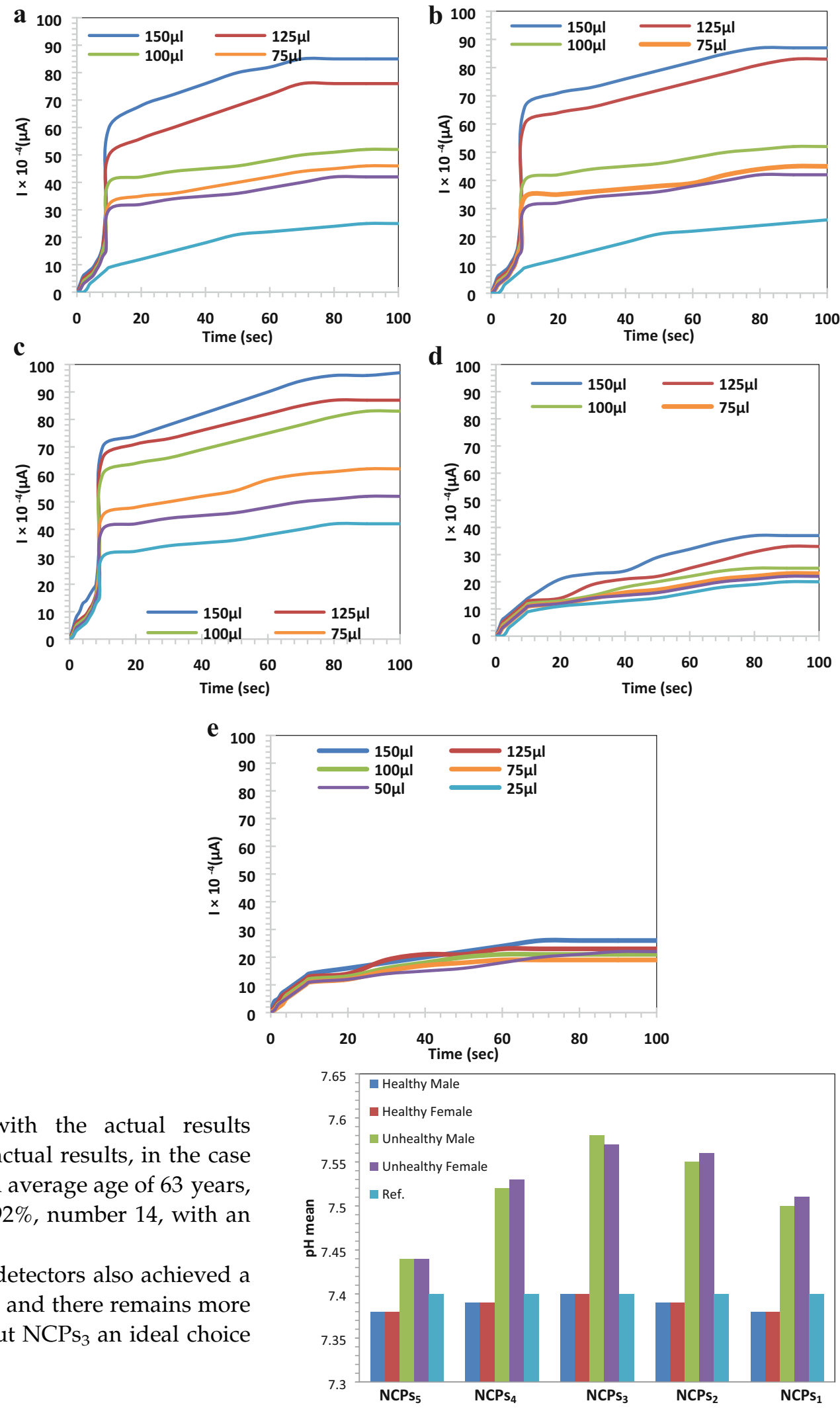

Fig. 7 The pH- results of $\mathbf{a} \mathrm{NCPs}_{1}$ and $\mathbf{b} \mathrm{NCPs}_{2}, \mathbf{c} \mathrm{NCPs}_{3}$, d $\mathrm{NCPs}_{4}, \mathbf{e} \mathrm{NCPs}_{5}$ 
Table 2 Sensitivity results for examined patients

\begin{tabular}{llllllllll}
\hline Gender & \multirow{2}{*}{ No } & Avg.Age & $\begin{array}{l}\mathrm{t}_{\mathrm{R}} \\
\mathrm{mg} / \mathrm{dl}\end{array}$ & \multicolumn{2}{l}{$\mathrm{S} \%$} & \multirow{2}{*}{ Result } \\
\cline { 5 - 8 } & & & & $\mathrm{NCPs}_{1}$ & $\mathrm{NCPs}_{2}$ & $\mathrm{NCPs}_{3}$ & $\mathrm{NCPs}_{4}$ & $\mathrm{NCPs}_{5}$ & \\
\hline Male & 23 & 45 & 173 & 11.3 & 22.8 & 77.3 & 18.7 & 5.8 & Negative \\
Female & 17 & 38 & 155 & 11.3 & 22.8 & 77.3 & 18.8 & 5.8 & Negative \\
Male & 11 & 53 & 275 & 41.3 & 51.6 & 85.1 & 41.9 & 23.2 & Positive/ Low \\
Female & 34 & 48 & 242 & 41.6 & 52.9 & 84.1 & 43.8 & 23.2 & Positive/ Low \\
Male & 45 & 63 & 368 & 67.6 & 77.6 & 93.2 & 57.7 & 37.3 & Positive/High \\
Female & 14 & 55 & 338 & 68 & 77.3 & 92.2 & 57.3 & 39.1 & Positive/High \\
Ref & 1 & - & 100 & 50 & & & & & Normal \\
\hline
\end{tabular}

\section{Conclusion}

In this work, we successfully synthesized different nanocomposites particles from $\mathrm{MgO}-\mathrm{MnO}_{2}$ with varied crystal structures via a milling method for cholesterol sensor applications. By altering the synthesis mixing ratio, three shapes were obtained: rods, hollows, and semi-spherical nanocomposites particles. The equivalent mixing ratio produces hollow tunnel structures that were systematically synthesized. Every combination has a different response to cholesterol. PH-responsive and uncharged nanocomposite particles were able to detect the change in the $\mathrm{pH}$ in a time of up to $10 \mathrm{~s}$ and with an efficiency exceeding 50\%. Moreover, the recorded current values were stable after only $80 \mathrm{~s}$, allowing accurate values to be obtained.

\section{References}

1. S. Dinc, B. Şahin, T. Kaya, Mater. Sci. Semicond. Process. 105, $104698(2020)$

2. E. Driggin, M.V. Madhavan, B. Bikdeli, T. Chuich, J. Laracy, G. Biondi-Zoccai, T.S. Brown, C.D. Nigoghossian, D.A. Zidar, J. Haythe, D. Brodie, J.A. Beckman, A.J. Kirtane, G.W. Stone, H.M. Krumholz, S.A. Parikh, J. Am. Coll. Cardiol. 75(18), 2352-2371 (2020)

3. D. Feng, Biomedical Information Technology, 2nd edn. Biomedical Engineering (2020) pp. 51-79, eBook ISBN: 9780128160350

4. B. Sahin, T. Kaya, Mater. Res. Express 6(4), 042003 (2019)

5. M.T. Awayiz, E.T. Salim, Mater. Sci. Forum 1002, 200-210 (2020)

6. A.D. Faisal, R.A. Ismail, W.K. Khalef, E.T. Salim, Opt. Quant. Electron. 52, 1-12 (2020)
7. L. Manjakkal, D. Szwagierczak, R. Dahiya, Prog. Mater. Sci. 109, 100635 (2020)

8. E.T. Salim, A.I. Hassan, S.A. Naaes, Mater. Res. Express 6(8), 086416 (2019)

9. C.W. Wong, Y.S. Chan, J. Jeevanandam, K. Pal, M. Bechelany, M. Abd Elkodous, G.S. El-Sayyad, J. Clust. Sci. 31, 367-389 (2020)

10. M.T. Awayiz, E.T. Salim, AIP Conf. Proc. 2213(1), 020247 (2020)

11. J. Jeevanandama, Y.S. Chana, M.K. Danquaha, Prot. Met. Phys. Chem. Surf. 55(2), 288-301 (2019)

12. A.A. Abdullah-Hamead, Mater. Sci. Forum 1002, 319-330 (2020)

13. E.T. Salim, R.A. Ismail, H.T. Halbos, Mater. Res. Express 6(11), 116429 (2019)

14. Q. Yang, J. Sha, L. Wang, Y. Wang, X. Ma, J. Wang, D. Yang, Nanotechnology 15(8), 1004 (2004)

15. H.A. Maishera, F.A. Kuta, J.O. Tijani, N.U. Adabara, A.S. Adedeji, J.D. Bala, J. Bio-Sci. 27, 109-120 (2019)

16. M.A. Fakhri, M.J. AbdulRazzaq, A.A. Alwahib, W.H. Muttlak, Opt. Mater. 109, 110363 (2020)

17. V. Masindi, Mater. Today 38(2), 1077-1087 (2021)

18. Y. Abdallah, S.O. Ogunyemi, A. Abdelazez, M. Zhang, X. Hong, E. Ibrahim, A. Hossain, H. Fouad, B. Li, J. Chen, Hindawi Biomed Res. Int., 2019, Article ID 5620989, 8 (2019)

19. H. Li, M. Li, W. Guo, X. Wang, C. Ge, B. Yang, Electrochim. Acta 123, 103-110 (2014)

20. J. Zhao, L. Qin, Y. Hao, Q. Guo, F. Mu, Z. Yan, Microchim. Acta 178, 439-445 (2012)

21. P. Karacabey, S. Döven, D. Uzunoğlu, A. Özer, Arab. J. Sci. Eng. 44, 9951-9964 (2019)

22. E.T. Salim, R.A. Ismail, H.T. Halbos, Appl. Phys. A 126, 891 (2020)

23. M. Zare, J. Dispersion Sci. Technol. (2020). https://doi.org/ 10.1080/01932691.2020.1737103

24. S.K. Alla, A.D. Verma, V. Kumar, R.K. Mandal, I. Sinha, N.K. Prasad, RSC Adv. 66, 61927-61933 (2016) 
25. M.A. Fakhri, E.T. Salim, M.H.A. Wahid, U. Hashim, Z.T. Salim, J. Mater. Sci.: Mater. Electron. 29(11), 9200-9208 (2018)

26. H.J. Ma, W.K. Jung, Y. Park, D.K. Kim, J. Mater. Chem. C 41, 11096-11103 (2018)

27. Z.T. Salim, U. Hashim, M.K.M. Arshad, M.A. Fakhri, E.T. Salim, Mater. Res. Bull. 86, 215-219 (2017)

28. K. Kannan, D. Sivasubramanian, P. Seetharaman, S. Sivaperumal, Optik 204, 164221 (2020)

29. M.A. Fakhri, U. Hashim, E.T. Salim, Z.T. Salim, J. Mater. Sci. Mater. Electron. 27(12), 13105-13112 (2016)

30. A. Azhari, M. Sharif, S.F. Golestanifard, A. Saberi, Mater. Chem. Phys. 124(1), 658-663 (2010)

31. F.G. Khalid, A.S. Ibraheam, M.A. Fakhri, N.H. Numan, AIP Conf. Proc. 2213(1), 020204 (2020)

32. K. Tamizh Selvi, K. Alamelu Mangai, M. Priya, S. Sagadevan, Physica B 594, 412355 (2020)

33. E.T. Salim, R.A. Ismail, M.A. Fakhri, B.G. Rasheed, Z.T. Salim, Iran. Sci. Technol. Trans. A 43(3), 1337-1343 (2019)

34. H. Wang, G. Li, A. Fakhri, J. Photochem. Photobiol. B 207, $111882(2020)$

35. H.A. Sallal, A.A. Abdul-Hamead, F.M. Othman, Eng. Technol. J. 38 Part A, 586-593 (2020)

36. Y. Huang, Y. Ji, Z. Kang, F. Li, S. Ge, D. Yang, J. Ruan, X. Fan, Chem. Eng. J. 395(1), 125098 (2020)

37. L. Liu, K. Morita, T.S. Suzuki, B. Kim, Ceram. Int. 46(9), 13669-13676 (2020)

38. R.A. Ismail, E.T. Salim, W.K. Hamoudi, Mater. Sci. Eng. C 33(1), 47-52 (2013)

39. Q.A. Hamad, M.S. Abed, J. Mech. Eng. Res. Dev. JMERD 42(5), 153-157 (2019)

40. J. Ma, S.G. Zhu, C.X. Wu, M.L. Zhang, Mater. Des. 30(8), 2867-2874 (2009)

41. Y. Dai, J. Huang, H. Zhang, C. Chiun Liu, Sens. Actuators B 281, 746-750 (2019)

42. Q. Zuo, Y. Chen, Z. Chen, R. Yu, Talanta 209, 120528 (2020)

43. Q. He, J. Liu, X. Liu, G. Li, D. Chen, P. Deng, J. Liang, Electrochim. Acta 296, 683-692 (2019)
44. T. Chhabra, A. Kumar, A. Bahuguna, V. Krishnan, Vacuum 160, 333-346 (2019)

45. L. Hao, L. Xue, F. Huang, G. Cai, W. Qi, M. Zhang, Q. Han, Z. Wang, J. Lin, Micromachines 11(3), 281 (2020)

46. T. Li, Z. Wang, D. Jiang, H. Wang, W. Lai, Y. Lv, Y. Zhai, Sens. Actuators B 290, 535-543 (2019)

47. N. Salehifar, Z. Zarghami, M. Ramezani, Mater. Lett. 167, 226-229 (2016)

48. M.A. Fakhri, Y. Al-Douri, U. Hashim, E.T. Salim, D. Prakash, K.D. Verma, Appl. Phys. B 121(1), 107-116 (2015)

49. X. Wang, Y. Li, J. Am. Chem. Soc. 124(12), 2880-2881 (2002)

50. A.L. Abed, W.K. Khalef, E.T. Salim, J. Phys. Conf. Ser. 795(1), 012031 (2021)

51. A.A. Abdul-Hamead, AIP Conf. Proc. 1968, 030017 (2018)

52. M.U. Khalid, M.F. Warsi, I. Shakir, M.F.A. Aboud, M. Shahid, S.S. Shar, S. Zulfiqar, Ceram. Int. 46(7), 9913-9923 (2020)

53. E.T. Salim, Surf. Rev. Lett. 20(05), 1350046 (2013)

54. M.A.M. Hassan, M.F.H. Al-Kadhemy, E.T. Salem, Int. J. Nanoelectron. Mater. 8(2), 69-82 (2014)

55. A. Kadhim, E.T. Salim, S.M. Fayadh, A.A. Al-Amiery, A.H. Kadhum, A.B. Mohamad, Sci. World J. 2014, Article ID 490951, 6 (2014)

56. X. Liu, S. Fu, C. Huang, Powder Technol. 154, 120-124 (2005)

57. M. Rezaei, M. Khajenoori, B. Nematollahi, Powder Technol. 205, 112-116 (2011)

58. N.M. El-Sawy, A.I. Raafat, N.A. Badawy, A.M. Mohamed, Int. J. Biol. Macromol. 142, 254-264 (2020)

59. Z. Zhang, Y. Ji, W. Chen, Chin. J. Chem. Eng. 28, 1405-1414 (2020)

60. E.T. Salim, J.A. Saimon, M.K. Abood, M.A. Fakhri, Opt. Quant. Electron. 52, 4631-4716 (2020)

Publisher's Note Springer Nature remains neutral with regard to jurisdictional claims in published maps and institutional affiliations. 